\title{
A Spotlight on Mobility and Interconnection in Rural vs. Urban Areas
}

\author{
Eva HASLAUER ${ }^{1}$, Dagmar SCHNÜRCH ${ }^{2}$ and Thomas PRINZ ${ }^{2}$ \\ ${ }^{1}$ Z_GIS, University of Salzburg/Austria·eva.haslauer@sbg.ac.at \\ ${ }^{2}$ Research Studios Austria, Studio iSPACE, Salzburg
}

This contribution was double-blind reviewed as full paper.

\begin{abstract}
Compact settlement structures, an economically operated public transport system and a sufficient provision with basic supply are often considered as a major goal in regional planning leading to a sustainable settlement development.

On the other hand living in single-family houses, lower costs of building land and the general wish of living in the green countryside are some driving forces for people to move to the outskirts of bigger cities, or to rural areas. These facts counteract the above mentioned goals in regional planning and also lead to high expenses for households concerning living and mobility in the long-term (this includes monetary costs as well as time expenses, travel distances, and $\mathrm{CO}_{2}$ emissions) and high infrastructure costs.

In this article, based on results of the Alpine Space project MORECO (Mobility and Residential Costs), the authors present a thorough GIS-based regional analysis of a research area in Salzburg, tackling the topics of demographic and settlement development, mobility, and travel behaviour. In order to point out long-term effects and follow-up costs at individual residential locations, an approach of a settlement cost calculator for mobility and accessibility calculations in the Salzburg pilot region is also presented in this paper.
\end{abstract}

\section{Introduction}

The aim of the MORECO project is to raise peoples' awareness of short-term as well as long-term costs and effects concerning living and mobility, when making residential choices. Furthermore spatial planners shall be supported to make sustainable decisions when assigning building land or re-densification areas. Thus a GIS-based regional analysis is conducted as basis for designing and implementing cost calculators to foster a sustainable settlement development, and provide information for political and regional decision makers.

This paper discusses the results of the above mentioned regional analysis and presents the current state of development to understand the on-going problems. Furthermore it describes the behaviour of the residential population and the measurements to raise peoples' awareness. 
The paper starts with an overview of analysed topics and derived indicators followed by an analysis concerning demography and settlement structures of the pilot region. This includes e.g. information about the residential population and the household structure. The next section concerns mobility and the quality of public supply, regarding public transport and supply facilities. The output of the analysis was finally used to create a cost calculator for settlement assessment, which is presented in the last section.

Most indicators characterizing the pilot region are based on statistical data provided by "STATISTIK AUSTRIA", the national statistical agency of Austria. Further sources are reports, e.g. from RAOS \& FASCHINGER (2008), and an extensive mobility study from HERRY et al. (2007).

Table 1 shows the indicators, which were derived for analysis and are presented in this article. They comprise the topics of demographic development (blue), mobility (yellow), settlement development (red) and interconnection (grey).

Table 1: Set of indicators / data collection

\begin{tabular}{|c|c|c|c|c|}
\hline Name & Data used & Year & Scale & Source \\
\hline $\begin{array}{l}\text { Population } \\
\text { development }\end{array}$ & Population census data & $\begin{array}{l}\text { 1971, 1981, 1991, } \\
\text { 2001, 2011 }\end{array}$ & Municipality & Statistik Austria \\
\hline Population projection & Projection of population & $\begin{array}{l}2007,2012,2017, \\
2022,2027,2032\end{array}$ & Municipality & Raos \& Faschinger \\
\hline Population density & $\begin{array}{l}\text { Population census data; } \\
\text { municipal area }\end{array}$ & 2011 & Municipality & Statistik Austria \\
\hline Household structure & $\begin{array}{l}\text { Number of households; } \\
\text { people in a household }\end{array}$ & $\begin{array}{l}\text { 1971, 1981, 1991, } \\
2001\end{array}$ & Municipality & Statistik Austria \\
\hline Modal Split & $\begin{array}{l}\text { Working people (place of } \\
\text { residence); traffic mode }\end{array}$ & 2001 & Municipality & Statistik Austria \\
\hline $\begin{array}{l}\text { Degree of } \\
\text { motorization }\end{array}$ & $\begin{array}{l}\text { Number of cars / 1,000 } \\
\text { inhabitants }\end{array}$ & $2006,2010,2012$ & Province & Land Salzburg, VCÖ \\
\hline Traffic development & $\begin{array}{l}\text { Traffic development } \\
\text { (individual, public) }\end{array}$ & 2006, 2007 & Province & Land Salzburg \\
\hline Traffic behaviour & Travel behaviour & 2005 & Province/districts & Herry et al. \\
\hline Residential area & Land for residential areas & 2010 & Municipality & Land Salzburg \\
\hline $\begin{array}{l}\text { Area consumption } \\
\text { per inhabitant }\end{array}$ & $\begin{array}{l}\text { Population census data; } \\
\text { land for residential areas }\end{array}$ & $\begin{array}{l}\text { 1976, 1983, 1999, } \\
\text { 2004, } 2007\end{array}$ & Municipality & $\begin{array}{l}\text { Land Salzburg, } \\
\text { Cadastre }\end{array}$ \\
\hline Settlement density & $\begin{array}{l}\text { Population census data; } \\
\text { residential area }\left(\mathrm{km}^{2}\right)\end{array}$ & 2011 & Municipality & Statistik Austria \\
\hline $\begin{array}{l}\text { Prices of building } \\
\text { land }\end{array}$ & EUR $/ \mathrm{m}^{2}$ building land & 2012 & Municipality & www.gewinn.at \\
\hline $\begin{array}{l}\text { Arguments for } \\
\text { densification }\end{array}$ & $\begin{array}{l}\text { Arguments for } \\
\text { densification }\end{array}$ & 2005,2010 & Province & Herry et al., VCÖ \\
\hline Commuting & $\begin{array}{l}\text { Working people (place of } \\
\text { residence) }\end{array}$ & 2001 & Municipality & Statistik Austria \\
\hline Travel costs & Minutes and distance & 2001 & Municipality & Land Salzburg \\
\hline $\begin{array}{l}\begin{array}{l}\text { Service areas of basic } \\
\text { supply }\end{array} \\
\end{array}$ & $\begin{array}{l}\text { Service areas around } \\
\text { service facilities }\end{array}$ & 2010 & Province & $\begin{array}{l}\text { Services from Land } \\
\text { Salzburg }\end{array}$ \\
\hline $\begin{array}{l}\text { Service areas of } \\
\text { public transport }\end{array}$ & $\begin{array}{l}\text { Service areas around bus } \\
\text { stops }\end{array}$ & 2009 & Province & $\begin{array}{l}\text { Public transport } \\
\text { stops from Land } \\
\text { Salzburg }\end{array}$ \\
\hline Customer potentials & $\begin{array}{l}\text { Population in service } \\
\text { areas }\end{array}$ & 2011 & $\begin{array}{l}\text { Province, } \\
\text { municipality }\end{array}$ & iSPACE \\
\hline
\end{tabular}




\section{Demographic and settlement indicators}

The Austrian pilot region is located in the north of the province of Salzburg and includes the districts of Salzburg-Umgebung and Salzburg city. The total number of population in 2011 in the pilot region was 290,443 (STATISTIK AUSTRIA 2011). Fig. 1 shows the population distribution as well as the population development from 1971 to 2011.

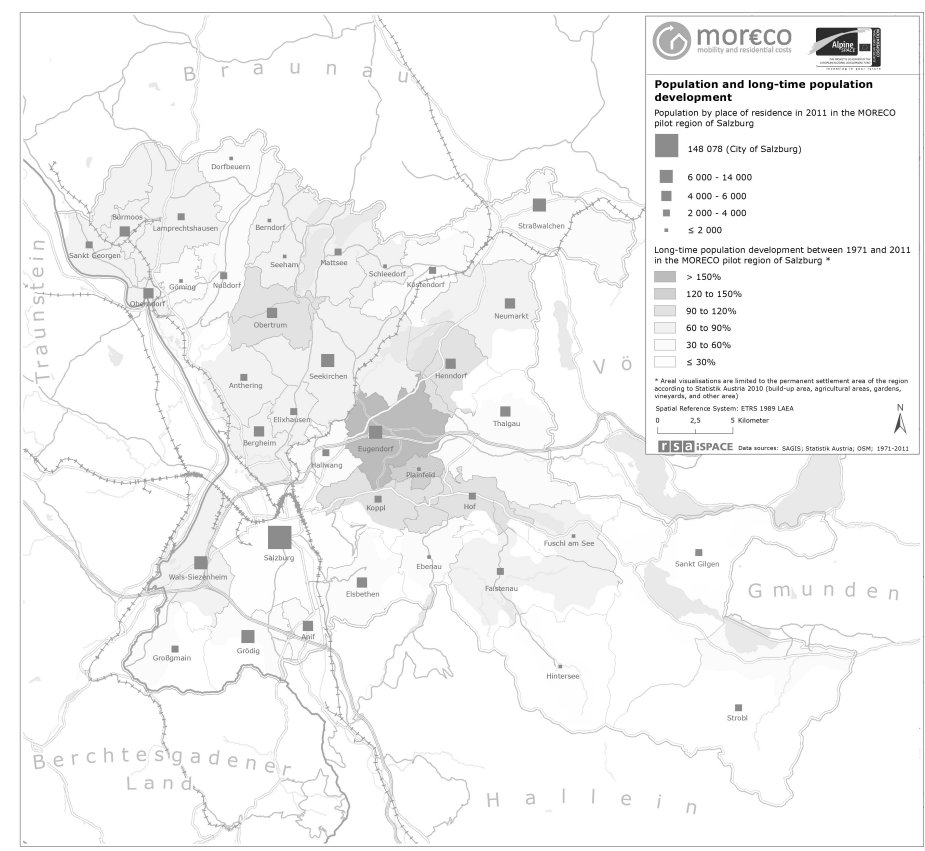

Fig. 1: Population and long-term population development in the pilot region

Concerning the future population development (2007-32) positive numbers are projected for most of the municipalities in the pilot region. Negative values are estimated only for Ebenau (>-5\%), Dorfbeuern ( -2.5 to $-5 \%$ ), and Anif (0 to $-2.5 \%)$ (RAOS \& FASCHINGER 2008).

Most households in the pilot region in 2011 were registered in the city of Salzburg $(68,693)$ Wals-Siezenheim $(4,468)$, and Seekirchen $(3,412)$. The average number of people living in one household in the pilot region was 3.6 in 1971 and decreased to 3.0 in 2001. The dominating household types in 2001 were one- and two-person households, just in four municipalities (Dorfbeuern, Faistenau, Göming, and Hintersee) four-person households were dominating. The highest proportions of one-person households in the pilot region were registered in the city of Salzburg (44\%) as well as in the surrounding municipalities Großgmain and Grödig (both 34\%), least proportions in Nußdorf (17\%), Hintersee (18.5\%), and Berndorf (19\%). The highest increases of one-person households from 1971 to 2001 were identified in Anif, Plainfield, and Elsbethen with a plus of about 15\% (STATISTIK 
AUSTRIA 2001). According to VCÖ (2007) the traffic volume will increase due to a rise in the number of one-person households, because many actions are household-related.

\section{Settlement indicators}

The population density (inhabitants $/ \mathrm{km}^{2}$ municipal area) is highest in the city of Salzburg $\left(2,254 \mathrm{inh} / \mathrm{km}^{2}\right)$, Oberndorf $\left(1,238 \mathrm{inh} / \mathrm{km}^{2}\right)$, and Bürmoos (686 inh/ $\left.\mathrm{km}^{2}\right)$. Strobl (39 inh/ $\left.\mathrm{km}^{2}\right)$, Sankt Gilgen $\left(38 \mathrm{inh} / \mathrm{km}^{2}\right)$, and Hintersee $\left(9.5 \mathrm{inh} / \mathrm{km}^{2}\right)$, have the least population densities. Another density parameter is the settlement density, which refers to the settlement area instead of municipal area. The highest settlement density $\left(\mathrm{inh} / \mathrm{km}^{2}\right.$ settlement area) in 2010 was calculated again for the city of Salzburg $\left(2,247 \mathrm{inh} / \mathrm{km}^{2}\right)$, Oberndorf, and Bürmoos (1,230.5 resp. $\left.677 \mathrm{inh} / \mathrm{km}^{2}\right)$ and the lowest values are noted in Strobl, Sankt Gilgen, and Hintersee, (38, 37 and 9 inh $/ \mathrm{km}^{2}$ ) (STATISTIK AUSTRIA 2011). According to the VCÖ (2010) there is a dependency between car ownership - or the degree of motorization - and density parameters, which is shown in Fig. 2. It is evident, that high settlement densities show a lower degree of motorization and thus produce less traffic.



Fig. 2: Relation between car ownership and urban density (VCÖ 2010)

As yet mentioned, one reason for people to move away from a city centre is the high price of building land. The average prices within the pilot region vary between $87.5 € / \mathrm{m}^{2}$ in Hintersee and $662.5 € / \mathrm{m}^{2}$ in the city of Salzburg. In comparison to 2011 , the prices of building land within some municipalities changed considerably. In the city of Salzburg, for example, the average price rose by $224.5 €$ (GEWINN VERLAG 2012).

Information about the availability of building land is given by the indicator of land consumption per day (see Fig. 3). The building land dataset was provided from the GeoInformation Service of Salzburg (SAGIS). This data contains built-up areas (red areas) extracted from aerial photos of 1976, which were updated in 1983, 1999, 2004, and 2007. The land consumption in the pilot region was $156 \mathrm{~m}^{2}$ per day on average between 1976 and 2007. The lowest consumption values were observed in Hintersee $\left(18 \mathrm{~m}^{2} /\right.$ year $)$, the highest ones in Seekirchen $\left(305 \mathrm{~m}^{2}\right)$, Wals-Siezenheim $\left(319 \mathrm{~m}^{2}\right)$, and Salzburg city $\left(1,582 \mathrm{~m}^{2}\right)$. Linked with inhabitants, the most residential building land per inhabitant in 2011 is registered in Sankt Gilgen with $410 \mathrm{~m}^{2}$, Strobl $\left(390 \mathrm{~m}^{2}\right)$, and Dorfbeuern $\left(345 \mathrm{~m}^{2}\right)$. The lowest values are observed in the city of Salzburg $\left(120 \mathrm{~m}^{2}\right)$, Hintersee $\left(170 \mathrm{~m}^{2}\right)$, and Elsbethen $\left(179 \mathrm{~m}^{2}\right)$. 


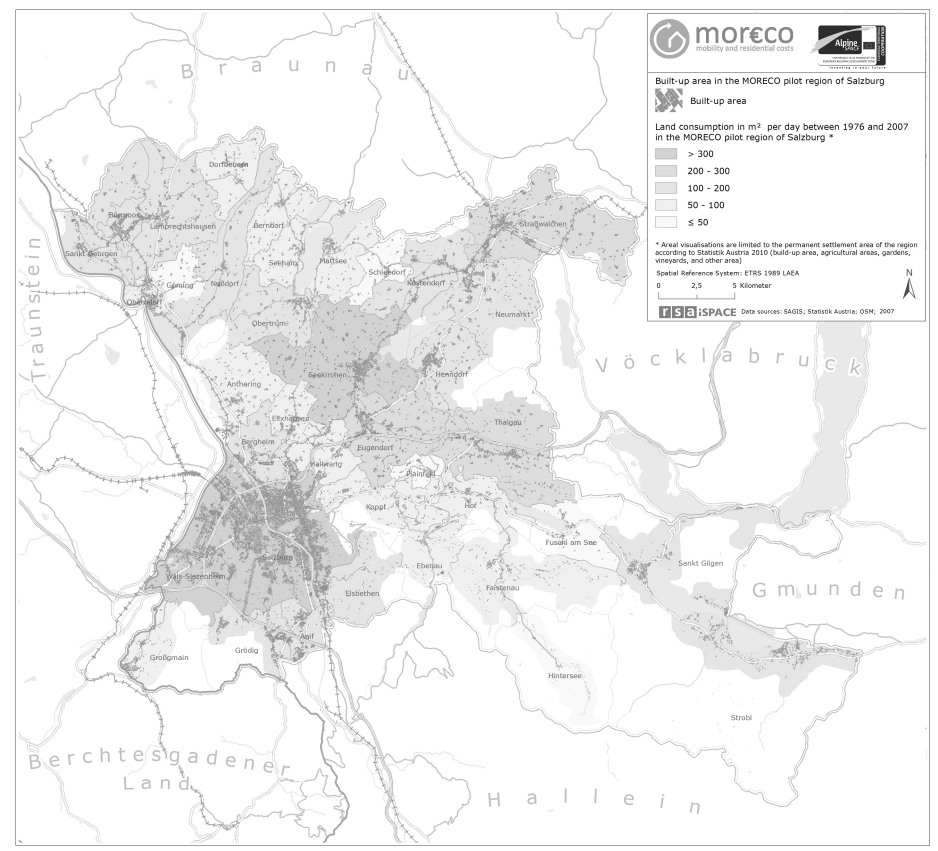

Fig. 3: Land consumption between 1976 and 2007

\section{Mobility and accessibility indicators}

\section{Degree of motorization}

The rate of motorization identifies the number of cars per 1,000 inhabitants in a certain region. In 2011 there were 527 cars on average in the whole province of Salzburg that fell upon 1,000 inhabitants, i.e. one car was used by 1.9 people. This indicator differs noticeably depending on the region: In the city of Salzburg 496 cars fell upon 1,000 inhabitants. This means one car was available for two persons. In rural regions, like the pilot region, there is a higher degree of motorization: In 2011 there were 581 cars per 1,000 inhabitants, thus one car was used by 1.7 persons. These numbers show that in $201158 \%$ of the people in the pilot region and only $50 \%$ of the people living in the city of Salzburg had a car available (STATISTIK AUSTRIA 2012). On average 76\% of all households in Austria own a car, thus an increase in households often means a rise in the number of cars, because many activities are household-related (see also section on Demographic and settlement indicators) (VCÖ 2007). 


\section{Traffic behaviour}

Next to motorization, also the traffic behaviour of the people changes depending on their residential location. Table 2 gives an overview of the traffic behaviour in 2004 (HERRY et al. 2007) in the city of Salzburg on the one hand, and in Salzburg-Umgebung and Hallein (rural areas) on the other hand. The samples refer to any random person older than six years in the respective districts, who left the house at least once during the observed period; only distances up to $300 \mathrm{~km}$ were considered.

Table 2: $\quad$ Traffic behaviour 2004 (HERRY et al. 2007)

\begin{tabular}{|c|c|c|}
\hline Traffic behaviour & City of Salzburg & Salzburg-Umgebung + Hallein \\
\hline Activities/day & 2.0 & 1.8 \\
\hline Frequency/day & 3.3 & 3.0 \\
\hline Total distance/day $(\mathrm{km})$ & 24.6 & 34.6 \\
\hline Average distance $(\mathrm{km})$ & 6.7 & 10.8 \\
\hline Total duration/day (min) & 69,4 & 70 \\
\hline Average duration $(\mathrm{min})$ & 21.4 & 23.3 \\
\hline
\end{tabular}

Table 2 presents that the average number of activities in Salzburg-Umgebung and Hallein was less than in Salzburg city (1.8 vs. 2.0) and also the number of paths per person (frequency) was slightly lower in Salzburg-Umgebung and Hallein (3.4) compared to the city (3.7). Regarding the total distance covered per day, a substantial difference is detected between the two districts: People from Salzburg-Umgebung and Hallein travelled $35 \mathrm{~km}$ on average and therefore about $10 \mathrm{~km}$ more than people in the city $(\sim 25 \mathrm{~km})$. People themselves estimated the average distance travelled per working day (walking and driving ways) in 2004 to be $10.8 \mathrm{~km}$ in Salzburg-Umgebung and Hallein, and $6.7 \mathrm{~km}$ in the city of Salzburg. Also the average travel duration per working day was estimated and amounts for $21.4 \mathrm{~min}$ in the city and 23.3min in Salzburg-Umgebung and Hallein (HERRY et al. 2007).

Regarding this information it can be stated, that the average distance of a trip in SalzburgUmgebung and Hallein is about $4 \mathrm{~km}$ longer than in the city, while the estimated average duration is only $2 \mathrm{~min}$ shorter in the city. Hence, it can be concluded that people in the city travel more often, but shorter in terms of time and distance. In other words, people in the districts of Salzburg-Umgebung and Hallein took fewer trips that were longer and more time-consuming.

\section{Commuting}

In 2001 there were 148,344 commuters in the pilot region (=employees by place of residence). When looking at commuter balances we distinguish between commuters travelling to outside of their originating municipality ("external commuters") and others, commuting within their originating municipality ("internal commuters"). Most of the internal commuters live in Salzburg city, Straßwalchen, and Sankt Gilgen. The lowest 
proportion is registered in Göming. In 2001 there were only seven municipalities considered as in-commuting municipalities (positive commuter balance), meaning, more people commuted in than out. These were Wals-Siezenheim (209\%), Bergheim (202\%), Salzburg city (143\%), Anif (141\%), Göming (141\%), Straßwalchen (107\%), and Eugendorf (105\%). All other municipalities had negative commuter balances. (STATISTIK AUSTRIA 2001) A GIS-based travel-time analysis in the pilot region shows that the longest distance covered by daily commuters (crossing municipalities) is from Strobl to Wals-Siezenheim with $61 \mathrm{~km}$ respectively $43 \mathrm{~min}$ (40 commuters). The shortest distance is between Anif and Grödig with $3 \mathrm{~km}$ resp. $4 \mathrm{~min}$ (132 people) (SAGIS 2007).

\section{Modal split}

BMVIT \& VCÖ (2008) showed that in 2007 more than 50\% of all distances in the province of Salzburg were covered by car. Besides, approximately $17 \%$ of the travels were taken by public transport, $11 \%$ by bike, and $18 \%$ by foot. Focusing on the MORECO pilot region, a slightly different modal split distribution is obtained. In 2004 even $65 \%$ of all travels were undertaken by motorized individual traffic, travels by foot covered about $15 \%$, by public transport $12 \%$, and by bike $6 \%$.

STATISTIK AUSTRIA analysed the commuters' choice of transport in 2001. Thereby external and internal commuters were analysed. The majority $(\sim 52 \%)$ of the internal commuters in Salzburg-Umgebung travelled by car, and around 3\% took a motorbike. The rest $(\sim 45 \%)$, made use of eco-mobility, i. e. on foot, by bike, or public transport. Compared to commuter flows only within the city of Salzburg, people in Salzburg-Umgebung made less use of ecomobility (-10\%). Thereby, the use of buses decreased significantly from $23 \%$ within the city to $2 \%$ in Salzburg-Umgebung. Turning to the modal split of external commuters in Salzburg-Umgebung, the situation was rather different: More than three-quarters $(81 \%)$ went by car or by motorbike. This represents an increase of more than $25 \%$ compared to internal commuters. Besides, the use of buses and trains gained a lot more importance $(10 \%$ and $7 \%$ respectively) (STATISTIK AUSTRIA 2001).

These analyses show a higher car-dependency in rural, often dispersed areas, and a higher usage of public transport in urban areas. To find out about how the modal split has changed, only values from the province of Salzburg, Salzburg-Umgebung, and Hallein are available (BMVIT \& VCÖ 2008, HERRY et al. 2007). The development between 1995 and 2004 resp. 2007 is presented in Tab. 3.

Table 3: Modal split of commuters in general in 1995 and 2004 resp. 2007

\begin{tabular}{|l|c|c|c|c|}
\hline \multirow{2}{*}{ Transport mode } & \multicolumn{2}{|c|}{ Province of Salzburg } & \multicolumn{2}{c|}{ Salzburg-Umgebung and Hallein } \\
\cline { 2 - 5 } & $\mathbf{1 9 9 5}$ & $\mathbf{2 0 0 7}$ & $\mathbf{1 9 9 5}$ & $\mathbf{2 0 0 4}$ \\
\hline Car (driver) & $39 \%$ & $45 \%$ & $56 \%$ & $65 \%$ \\
\hline By foot & $25 \%$ & $18 \%$ & $22 \%$ & $14 \%$ \\
\hline Public transport & $17 \%$ & $17 \%$ & $15 \%$ & $12 \%$ \\
\hline Car (passenger) & $10 \%$ & $9 \%$ & n. d. & n. d. \\
\hline Bike & $8 \%$ & $11 \%$ & $7 \%$ & $7 \%$ \\
\hline
\end{tabular}


Summing up, the development of Salzburg-Umgebung and Hallein in the past twelve years shows a substantial increase of car use (driver) from $56 \%$ to $65 \%$ and a decrease of travels by foot from $22 \%$ to $14 \%$ (BMVIT \& VCÖ 2008). This rise is important when considering that the number of commuters rose by a quarter between 1991 and 2006 in Austria (VCÖ 2007) and will further increase in future. The development will thus have a strong effect on future traffic volume.

\section{Accessibility indicators}

In order to measure the accessibility in the pilot region, network- and potential-analyses are conducted. To compare supply and demand in the public transport sector, public transport stops of bus and local trains in the pilot region (provided by SAGIS in 2009) are analysed concerning their customer potential, see Fig. 4. Therefore service areas of 500m walking distance around bus stops and $1,000 \mathrm{~m}$ around train stops are calculated and a population grid (250x250m) from 2008 is overlaid (STATISTIK AUSTRIA 2008).



Fig. 4: Public transport stops in the pilot region and their customer potential

From this intersection the number of inhabitants within the service area was summed. The analysis shows that $222,504(78 \%)$ people live within a distance of $500 \mathrm{~m}$ around bus stops, $13,915(5 \%)$ people live within $1,000 \mathrm{~m}$ around train stops, and 50,748 (18\%) live outside of both distances ${ }^{1}$. In the same way the customer potential of selected local supply facilities (schools, supervision and care centres, medical care, daily supply facilities, posts, and

\footnotetext{
1 Relative shares refer to the population in the whole pilot region in 2008: 287,167 people.
} 
banks) outside the city region was analysed. Service areas were calculated for walking distances of $1,000 \mathrm{~m}$ and $2,000 \mathrm{~m}$ and a population grid with a cell size of $250 \times 250 \mathrm{~m}$ from 2008 is overlaid again. In the rural pilot region of Salzburg (excluding the inhabitants and area of Salzburg city) there are 91,091 people (65\%) living within $1,000 \mathrm{~m}$, and 28,156 people $(20 \%)$ living within $2,000 \mathrm{~m}$ around service facilities. 19,923 (15\%) people live outside of both areas ${ }^{2}$. In order to foster regions of short ways it is necessary to guarantee the availability of supply facilities in walking or bike-riding distance, and connectivity to an effective public transport network with a good service frequency. Therefore spatial planning and mobility planning have to go in line. Regions of short ways can help to decrease car-dependency and thus reduce traffic (VCÖ 2007).

\section{Conclusion and Outlook}

Population increases mainly in the city of Salzburg and in its surrounding municipalities. This is indicated by the short term, the long term, and also the future development. At the same time the households in the region are getting smaller and smaller. Yet the one-person households are the dominating household type in many regions. Due to the link between household-numbers and motorization, this trend leads to an increase of individual motorized traffic. Car ownership generally also increases in areas with lower settlement densities. Thus the motorization rate is highest in dispersed settlement structures. One criterion that even supports people to move to areas with lower settlement densities is the price per $\mathrm{m}^{2}$ of building land; highest rises of price are registered in the city of Salzburg and its surrounding municipalities.

The different residential locations (rural/urban) influence also the distances covered per day and the mode of transport. In the city centre (densely populated area) the mean travel distance per day is only half the travel distance in surrounding municipalities. Additionally more than one third of the distances within the city are travelled by eco-mobility, whereas in surrounding municipalities it is only a quarter of the distances. Especially commuters travelling across the boundaries of their originating municipality mostly use the car. The travel behaviour in the pilot region between 1983 and 2004 further changed in a way that travels per person and day increased as well as the total duration of travel.

Altogether it can be stated, that living in the city - and thus in densely populated areas decreases car ownership, travel-distance and -time, and in turn monetary travel costs. At the same time it fosters an environmentally friendly eco-mobility, because people in the city in general make use of public transport more often.

The presented findings and results are in the next step included into a mobility- and settlement costs calculator. It shall support spatial and regional planners to assign costs to newly designated building land. The calculator treats topics like distances to the next social infrastructure (kindergartens, schools, medical treatment), to local food supply, leisure-time facilities, public transport stops, regional centres, or the next working centre. Further indicators are included showing the settlement's quality, e.g. availability of private green space, connection to bike/foot paths, or service interval of public transport.

2 Relative shares refer to the total population in the pilot region in 2008, excl. Salzburg city:139,170. 




Fig. 5: Impression of the mobility and settlement costs calculator

Fig. 5 gives an impression of the developed mobility and settlement costs calculator. In the next step of development the cost calculator will be pre-filled with data, which comes from the analysis presented in this report. Integrating regional datasets from the analysis will automate the tool. Further improvements aim to make it more user-friendly and allow an objective comparison of different locations.

\section{References}

BMVIT \& VCÖ (2008), Der Modal Split in Österreichs Bundesländern im Jahr 2007. http://doku.cac.at/vcoe_mobilitaetsform_nach_bundesland_vgl_95-07.pdf (09/2012).

GEWINN VERLAG (2012), Grundstückspreisliste Sälzburg 2012. http://www.gewinn.com/immobilien/preisuebersichten/salzburg/ (07/2012).

Herry, M., SEDlaceK, N. \& Steinacher I. (2007), Verkehr in Zahlen. Wien.

LAND SALZBURG/SAGIS (2007), Distanz- und Fahrzeitmatrix 2007.

RAOS J. \& FASCHINGER N. (2008), Bevölkerung Land Salzburg \& Regionen 2007-2032. Salzburg.

STATISTIK AUSTRIa (2001-2011), Regionalstatistische Raster. http://www.statistik.at/web_de/klassifikationen/regionale_gliederungen/regionalstatistis che_rastereinheiten/ (03/2012).

STATISTIK AUSTRIA (2001-2011), ISIS - Statistische Datenbank. http://www.statistik.at/web_en/publications_services/isis_database/index.html (09/2012).

StatistiK Austria (2012), Kfz-Bestand 2011. http://www.statistik.at/web_de/statistiken/verkehr/strasse/kraftfahrzeuge_bestand/index.html (09/2012).

VCÖ (2007), Mobilität und Verkehr im demografischen Wandel. VCÖ Schriftenreihe „Mobilität mit Zukunft", 1/2007. Wien.

VCÖ (2007), Einfluss der Raumordnung auf die Verkehrsentwicklung. VCÖ Schriftenreihe „Mobilität mit Zukunft“, 3/2007. Wien

VCÖ (2010), Wie wohnen Mobilität lenkt. VCÖ Schriftenreihe „Mobilität mit Zukunft“ $4 / 2010$. Wien 